Riris Harisa ${ }^{1}$

Melvi Lesmana Alim²

Vitri Anggraini ${ }^{3}$

\title{
Meningkatkan Kemampuan Kognitif dalam Mengenal Warna Melalui Media Lotto
}

\begin{abstract}
Abstrak
Penelitian ini bertujuan untuk meningkatkan kemampuan kognitif dalam mengenal warna melalui media lotto warna pada anak kelompok A di TK plamboyan mekar desa tanjung sawit. Jenis penelitian adalah Penelitian Tindakan Kelas yang dilakukan secara kolaboratif antara peneliti dengan guru kelas. Penelitian ini terdiri dari dua siklus dan setiap siklusnya dilaksanakan dua kali pertemuan. Subjek penelitian ini adalah 20 anak kelompok A TK Plamboyan Mekar yang terdiri dari 9 anak laki-laki dan 11 anak perempuan. Teknik pengumpulan data melalui observasi dan dokumentasi. Instrumen yang digunakan dalam penelitkian ini adalah lembar observasi (chek list) dan dokumentasi. Teknik analisis data dilakukan secara deskriptif kuantitatif. Hasil penelitian menunjukan bahwa terdapat peningkatan kemampuan mengenal warna setelah menggunakan media lotto warna. Kemampuan kognitif anak dalam setiap siklus mengalami perkembangan. Hal ini dapat diketahui dari hasil penilaian pada Pra tindakan kemampuan kognitif anak sebanyak $34,6 \%$ berada dalam kriteria belum berkembang, pada Siklus I diperoleh 53,75\% dalam kriteria mulai berkembang dan pada Siklus II diperoleh $81,56 \%$ dalam kriteria berkembang sangat baik.
\end{abstract}

Kata kunci: Kemampuan, kognitif, lotto warna

\begin{abstract}
This research is aimed at improving children's cognitive ability in understading color through lotto color media in group A TK Plamboyan Mekar Desa Tanjung Sawit is a Classroom Action Research (CAR), it was conducted by the researcher and classroom teacher collaboratively. This research was conducted in two cycles in which each cycles consists of two meetings. Subject of the research 20 children of group A in TK Plamboyan Mekar, 9 boys and 11 girls. the instruments employed were observation sheet (check list) and documentation. Technique of data collection were observation and documentation. The data were analysed descriptive qualitatively. The findings showed that there was an improvement on research psycomotor after applying lotto color media. The children's cognitive abilities in every cycle was increased. It can be shown by the data obtained in Pre-Action 34.6\% with the criteria undeveloped, cycle I with $53.75 \%$, with criteria began to grow, cycle II $81.56 \%$, well developed.
\end{abstract}

Keywords: Ability, cognitive, lotto color

\footnotetext{
${ }^{1}$ Prodi PG-PAUD Universitas Pahlawan Tuanku Tambusai, Riau, Indonesia

Email : ririsharisa@yahoo.com

${ }^{2}$ Prodi PG-PAUD Universitas Pahlawan Tuanku Tambusai, Riau, Indonesia

${ }^{3}$ Prodi Bahasa Inggris Universitas Pahlawan Tuanku Tambusai, Riau, Indonesia
}

Aulad : Journal on Early Childhood, 2018, 1(1), 78 - 84 


\section{PENDAHULUAN}

Taman Kanak-kanak (TK) sebagai lembaga pendidikan anak usia dini pada jalur formal mengandung makna "tempat yang aman dan nyaman (safe and comfortable) untuk bermain, sehingga pelaksanaan pendidikan di TK harus mampu menciptakan lingkungan bermain yang aman dan nyaman sebagai wahana tumbuh kembang anak. Pada usia dini perkembangan anak akan berkembang secara optimal, karena pada masa ini merupakan peletakkan dasar pertama dalam mengembangkan kemampuan fisik, kognitif, bahasa, sosial emosional, dan nilai agama moral. Usia ini sering disebut sebagai usia emas (Golden Age), karena masa ini akan terjadi perkembangan yang pesat terhadap semua aspek perkembangan dan akan terjadi sekali dalam seumur hidup, dan tidak akan kembali lagi setelah anak-anak dewasa nantinya.

Pembelajaran yang menyenangkan dapat dilakukan dengan konsep "belajar sambil bermain" atau "bermain sambil belajar". Dalam konsep tersebut guru dapat melakukannya dengan cara penggunaan alat peraga atau disebut juga alat permaianan edukatif yang dirancang untuk memenuhi kebutuhan perkembangan anak dalam melaksanakan fungsi perkembanganya. Permainan edukatif ini bertujuan untuk memudahkan anak dalam mengingat konsep- konsep yang akan dipelajari anak tanpa perlu bimbingan sehingga memungkinkan anak belajar secara mandiri.

Berdasarkan kurikulum peraturan mentri nomor 58 tahun 2009, tetang standar pendidikan anak usia dini meliputi pendidikan formal dan non formal antara lain terdiri atas: standar tingkat pencapaian perkembangan, standar pendidikan, dan tenaga kependidikan, standar isi, proses dan penilaian. (wahyunigsih, 2010:1). Maka pada anak usia 4 - 5 tahun diharapkan mampu menunjuk dan mencari sebanyak-banyaknya benda yang mempunyai warna, mengelompokkan benda menurut warna, memasangkan benda sesuai dengan warna. Maka dari itu guru sebaiknya menggunakan media permainan yang menarik agar proses belajar mengajar di sekolah menjadi lebih menyenangkan dan berkesan bagi anak.

Pendidikan Anak Usia Dini (PAUD) mengatakan alat permainan edukatif sebagai segala sesuatu yang dapat digunakan sebagai sarana atau prasarana untuk bermain yang mengandung nilai edukatif (pendidikan) dan dapat mengembangkan seluruh kemampuan anak. Sementara Eliyawati (2005:23), mengatakan bahwa alat permaianan edukatif sengaja di rancang secara khusus untuk kepentingan pendidikan. Selain itu alat permainan edukatif ini dirancang bertujuan unutk meningkatkan perkembangan fisik(motorik halus dan motorik kasar), emosi, sosial, bahasa, moral dan kognitif.

Berdasarkan pengamatan sementara yang peneliti lakukan tanggal 12 Februari 2018 di TK Plamboyan Mekar Desa Tanjung Sawit Kecamatan Tapung Kabupaten Kampar pada anak kelompok A yang berusia 4-5 tahun didapat jumlah sebanyak 20 anak terdiri dari 9 anak laki-laki dan 11 anak perempuan. Penguasaan dalam hal kemampuan mengenal warna di TK Plamboyan Mekar Desa Tanjung Sawit Kecamatan Tapung Kabupaten Kampar masih rendah karena pada kegiatan pembelajaran pengenalan warna sebatas pemberian tugas mewarnai dan menyebutkan warna sesuai perintah guru dikarenakan keterbatasan media belajar yang dimiliki, sehingga banyak anak dalam menyebut warna tidak sesuai dengan warna yang ada atau bahkan ada anak yang sama sekali tidak mau menyebutkan warna sesuai perintah guru.

Masih terlihat anak-anak yang jarang memahami warna atau kurang mengetahui tentang warna, anak-anak masih kesulitan dalam menyebutkan warna utama atau warna dasar. Selain itu guru juga masih kurang mengenalkan warna-warna kepada anakanaknya sehingga anak-anak masih kesulitan dalam mengenal warna, kurangnya media 
pembelajaran untuk mengenal warna yang disediakan disekolah masih belum ada. Hal ini menjadikan anak sulit untuk mengenal warna.

Solusi yang dilakukan untuk mengatasi permasalahan tersebut adalah dengan perbaikan pembelajaran dengan menggunakan media yang tepat dan dilakukan dengan permainan yang menyenangkan akan membuat anak-anak semangat dan mudah memahami materi tentang warna. Media Lotto yaitu suatu permainan yang bertujuan mengembangkan daya konsentrasi dan pengamatan anak. Permainan ini dapat dimainkan secara perorangan ataupun berkelompok oleh anak. Bahan yang digunakan adalah triplek atau kertas karton berukuran 17,5 x 17,5 cm dengan jumlah 9 buah.

\section{METODE PENELITIAN}

Penelitian ini menggunakan jenis penelitian tindakan kelas (PTK), Arikunto (2010) menyatakan bahwa PTK adalah penelitian yang dilakukan oleh guru di dalam kelasnya sendiri melalui refleksi diri, dengan tujuan untuk memperbaiki kinerjanya sebagai guru, sehingga hasil belajar anak menjadi meningkat. Penelitian ini bertujuan untuk meningkatkan kemampuan kognitig mengenal warna melalui media lotto warna pada anak kelompok A TK Plamboyan Mekar Desa Tanjung Sawit Kecamatan Tapung Kabupaten Kampar.

Dalam penelitian ini menggunakan bagan alur penelitian Arikunto, dilaksanakan dalam dua siklus yaitu siklus I dan siklus II.. Dimana dalam satu siklus terdiri dari empat tahapan yaitu perencanaan (planning), tindakan (acting), pengamatan (observasi) dan refleksi (reflecting)

Berapapun banyak data yang terkumpul, tidak akan bermakna sebelum data tersebut dianalisa dan diolah. Dengan terkumpulnya data maka langkah selanjutnya adalah menganalisis data tersebut. Tehnik analisis data yang digunakan dalam penelitian ini adalah tehnik Deskriptif Kompratif dan Analisis Kritis.

Data yang diperoleh pada penelitian ini adalah data tentang kreativitas, dianalisis dengan teknik analisis deskriptif. Analisis data yang dilakukan secara deskriptif bertujuan untuk menggambarkan data tentang aktivitas guru dan anak selama proses pembelajaran, dan data ketercapaian hasil belajar. Untuk menentukan motorik halus anak diolah dengan menggunakan rumus persentase Arikunto (2010), yaitu sebagai berikut :

\section{$\mathrm{P}=\underline{\text { Posrate }- \text { Baserate }} \times 100 \%$ \\ Baserate}

Keterangan:

$\mathrm{P} \quad=$ Persentase peningkatan

Posrate $\quad=$ Nilai sesudah dilakukan tindakan

Baserate $\quad=$ Nilai sebelum dilakukan tindakan

$100 \%=$ Bilangan Tetap

Sedangkan untuk kategori penilaian, maka dalam hal ini digunakan panduan sebagai berikut:

a. $76 \%-100 \%$ baik,

b. $56 \%-75 \%$ cukup

c. $55 \%-0 \%$ kurang.

Untuk menentukan keberhasilan aktivitas guru dan aktivitas anak selama proses pembelajaran diolah dengan menggunakan rumus persentase, yaitu sebagai berikut :

$$
p=\frac{\mathrm{F}}{\mathrm{N}} \times 100 \%
$$


Keterangan:

$\begin{array}{ll}\mathrm{f} & =\text { Frekuensi yang sedang dicari persentasenya } \\ \mathrm{N} & =\text { Number of Cases (jumlah frekuensi/banyaknya individu) } \\ \mathrm{P} & =\text { Angka persentase } \\ 100 \% & =\text { Bilangan Tetap }\end{array}$

Dalam menentukan kriteria penilaian tentang hasil penelitian aktivitas guru selama proses pembelajaran dengan penerapan kegiatan menari, maka dilakukan pengelompokkan atas 4 kriteria penilaian yaitu sangat tinggi, tinggi, cukup tinggi dan rendah. Adapun kriteria menurut Arikunto (2010) persentase tersebut yaitu sebagai berikut:
a) $76 \%-100 \%$ tergolong sangat tinggi (BSB)
b) $56 \%-75 \%$ tergolong tinggi $(\mathrm{BSH})$
c) $41 \%-55 \%$ tergolong cukup tinggi (MB)
d) $40 \%$ kebawah tergolong rendah (BB)

\section{HASIL DAN PEMBAHASAN}

Pelaksanaan siklus I dilaksanakan selama 2 kali pertemuan yaitu tanggal 8 dan 9 Mei 2018. Tema pembelajaran ditentukan oleh peneliti bersama dengan guru kelas selaku kolaborator. Tema pada siklus I adalah Pekerjaan dengan sub tema Bidang Keamanan.

Hasil Observasi Kemampuan Kognitif Anak Dalam Mengenal Warna Pada Kelompok A di TK Plamboyan Mekar Desa Tanjung Sawit

\begin{tabular}{|c|c|c|c|c|}
\hline \multirow{3}{*}{ No } & \multirow{3}{*}{$\begin{array}{c}\text { Kemampuan Kognitif Anak } \\
\text { Dalam Mengenal Warna }\end{array}$} & \multicolumn{3}{|c|}{ Siklus I } \\
\hline & & & \multicolumn{2}{|c|}{ Jumlah Anak } \\
\hline & & & Pertemuan 1 & Pertemuan 2 \\
\hline & & BB & 4 & 2 \\
\hline & & MB & 15 & 15 \\
\hline & & $\mathrm{BSH}$ & 1 & 3 \\
\hline & & BSB & 0 & 0 \\
\hline & & BB & 5 & 1 \\
\hline & & MB & 13 & 15 \\
\hline & & $\mathrm{BSH}$ & 2 & 4 \\
\hline & & BSB & 0 & 0 \\
\hline & & $\mathrm{BB}$ & 5 & 1 \\
\hline & & MB & 13 & 13 \\
\hline & & $\overline{\mathrm{BSH}}$ & 2 & 6 \\
\hline & & BSB & 0 & 0 \\
\hline & & $\mathrm{BB}$ & 0 & 0 \\
\hline & & MB & 18 & 17 \\
\hline & & $\mathrm{BSH}$ & 2 & 3 \\
\hline & & BSB & 0 & 0 \\
\hline
\end{tabular}

Keterangan:

BB : Rendah, diberi skor 1 artinya anak didik belum memperlihatkan perkembangan indikator penelitian.

MB : Cukup Tinggi, diberi skor 2 artinya anak didik mulai memperlihatkan perkembangan indikator penelitian.

BSH : Tinggi, diberi skor 3 artinya anak didik telah memperlihatkan perkembangan indikator penelitian.

BSB : Sangat Tinggi, diberi skor 4 artinya anak didik telah mencapai indikator penelitian secara keseluruhan. 
Rekapitulasi Observasi Kemampuan Kognitif Anak Dalam Mengenal Warna Pada Kelompok A di TK Plamboyan Mekar Desa Tanjung Sawit Pada Siklus I

\begin{tabular}{|c|l|l|l|l|l|l|l|l|}
\hline $\begin{array}{c}\text { Tahap } \\
\text { Siklus I }\end{array}$ & \multicolumn{2}{|c|}{$\begin{array}{c}\text { Belum } \\
\text { berkembang }\end{array}$} & \multicolumn{2}{c|}{$\begin{array}{c}\text { Mulai } \\
\text { berkembang }\end{array}$} & $\begin{array}{c}\text { Berkembang } \\
\text { sesuai } \\
\text { harapan }\end{array}$ & $\begin{array}{c}\text { Berkembang } \\
\text { sangat baik }\end{array}$ \\
\cline { 2 - 10 } & $F$ & $\%$ & $F$ & $\%$ & $F$ & $\%$ & $F$ & $\%$ \\
\hline Pertemuan 1 & 14 & $17,5 \%$ & 59 & $73,75 \%$ & 7 & $8,75 \%$ & 0 & $0 \%$ \\
\hline Pertemuan 2 & 4 & $5 \%$ & 60 & $75 \%$ & 16 & $20 \%$ & 0 & $0 \%$ \\
\hline
\end{tabular}

Dari tabel IV.5 dan IV.6 dapat diketahui bahwa pada Siklus I terdapat 2 pertemuan. Pertemuan 1 yang terdiri dari 20 anak, jumlah anak yang belum berkembang ada 14 anak (17,5\%), anak yang mulai berkembang ada 59 anak $(73,75 \%)$, anak yang berkembang sesuai harapan ada 7 anak $(8,75)$ dan berkembang sangat baik masih belum ada. Sedangkan pada pertemuan 2 jumlah anak yang belum berkembang ada 4 anak (5\%), anak yang mulai berkembang ada 60 anak (75\%), anak yang berkembang sesuai harapan ada 16 anak (20) dan berkembang sangat baik masih belum ada.

Siklus II pertemuan pertama dilaksanakan pada hari Selasa tanggal 17 Mei 2018, pertemuan kedua hari Jum'at tanggal 18 Mei 2018. Tema pembelajaran yaitu alam semesta dengan gejala alam.

Hasil Observasi Kemampuan Kognitif Anak Dalam Mengenal Warna Pada Kelompok A di TK Plamboyan Mekar Desa Tanjung Sawit

\begin{tabular}{|c|c|c|c|c|}
\hline \multirow[t]{3}{*}{ No } & \multirow{3}{*}{$\begin{array}{c}\text { Kemampuan Kognitif Anak } \\
\text { Dalam Mengenal Warna }\end{array}$} & \multicolumn{3}{|c|}{ Siklus I } \\
\hline & & & \multicolumn{2}{|c|}{ Jumlah Anak } \\
\hline & & & Pertemuan 1 & Pertemuan 2 \\
\hline & & $\mathrm{BB}$ & 10 & 4 \\
\hline & & MB & 10 & 16 \\
\hline & & $\mathrm{BSH}$ & 0 & 0 \\
\hline & & BSB & 0 & 0 \\
\hline & & $\mathrm{BB}$ & 10 & 5 \\
\hline & & $\mathrm{MB}$ & 10 & 13 \\
\hline & & $\mathrm{BSH}$ & 0 & 2 \\
\hline & & BSB & 0 & 0 \\
\hline & & $\mathrm{BB}$ & 11 & 5 \\
\hline & & MB & 9 & 13 \\
\hline & & $\overline{\mathrm{BSH}}$ & 0 & 2 \\
\hline & & BSB & 0 & 0 \\
\hline & & $\mathrm{BB}$ & 3 & 0 \\
\hline & & MB & 17 & 18 \\
\hline & & $\mathrm{BSH}$ & 0 & 2 \\
\hline & & BSB & 0 & 0 \\
\hline
\end{tabular}

Keterangan:

BB : Rendah, diberi skor 1 artinya anak didik belum memperlihatkan perkembangan indikator penelitian.

MB : Cukup Tinggi, diberi skor 2 artinya anak didik mulai memperlihatkan perkembangan indikator penelitian.

BSH : Tinggi, diberi skor 3 artinya anak didik telah memperlihatkan perkembangan indikator penelitian.

BSB : Sangat Tinggi, diberi skor 4 artinya anak didik telah mencapai indikator penelitian secara keseluruhan. 
Rekapitulasi Observasi Kemampuan Kognitif Anak Dalam Mengenal Warna Pada Kelompok A di TK Plamboyan Mekar Desa Tanjung Sawit Pada Siklus II

\begin{tabular}{|c|l|l|l|l|l|l|l|l|}
\hline $\begin{array}{c}\text { Tahap } \\
\text { Siklus II }\end{array}$ & \multicolumn{2}{|c|}{$\begin{array}{c}\text { Belum } \\
\text { berkembang }\end{array}$} & \multicolumn{2}{c|}{$\begin{array}{c}\text { Mulai } \\
\text { berkembang }\end{array}$} & $\begin{array}{c}\text { Berkembang } \\
\text { sesuai } \\
\text { harapan }\end{array}$ & \multicolumn{2}{c|}{$\begin{array}{c}\text { Berkembang } \\
\text { sangat baik }\end{array}$} \\
\cline { 2 - 10 } & $F$ & $\%$ & $F$ & $\%$ & $F$ & $\%$ & $F$ & $\%$ \\
\hline Pertemuan 1 & 0 & $0 \%$ & 49 & $61,25 \%$ & 31 & $38,75 \%$ & 0 & $0 \%$ \\
\hline Pertemuan 2 & 0 & $0 \%$ & 13 & $16,25 \%$ & 43 & $53,75 \%$ & 24 & $30 \%$ \\
\hline
\end{tabular}

Dari tabel IV.9 dan IV.10 dapat diketahui bahwa pada Siklus II terdapat 2 pertemuan. Pertemuan 1 yang terdiri dari 20 anak, jumlah anak yang belum berkembang tidak ada, anak yang mulai berkembang ada 49 anak $(61,25 \%)$, anak yang berkembang sesuai harapan ada 31 anak $(38,75)$ dan berkembang sangat baik masih belum ada. Sedangkan pada pertemuan 2 jumlah anak yang belum berkembang tidak ada, anak yang mulai berkembang ada 13 anak (16,25\%), anak yang berkembang sesuai harapan ada 43 anak (53,75\%) dan berkembang sangat baik masih ada 24 anak (30\%).

Dengan melihat hasil dari pengamatan langsung di dalam kelas bahwa kemampuan kognitif anak dalam mengenal warna dapat ditingkatkan dengan media lotto warna. Pada saat anak menggunakan media lotto warna kemampuan kognitif anak terus meningkat. Media lotto warna tersebut dapat dikatakan membantu anak dalam mengembangkan dan meningkatkan kemampuan kognitif anak dalam mengenal warna. Hal tersebut sudah dilakukan anak dalam penelitian siklus II ini dan hasil yang diperoleh jauh lebih baik dari siklus I karena ada yang sedikit perbedaan yang menjadikan perubahan tersebut terus meningkat.

\section{SIMPULAN}

Berdasarkan hasil penelitian dapat disimpulkan bahwa melalui media lotto warna dapat meningkatkan kemampuan kognitif anak dalam mengenal warna Kelompok A TK Plamboyan Mekar. Kemampuan kognitif anak dalam mengenal warna melalui media lotto warna dapat ditingkatkan dengan menggunakan strategi pembelajaran dalam menggunakan media lotto warna.

Berdasarkan hasil data yang diperoleh bahwa kemampuan kognitif anak dalam setiap siklus mengalami perkembangan. Hal ini dapat diketahui dari hasil penilaian dimana pada Pra tindakan diperoleh $34,6 \%$ dalam kriteria belum berkembang selanjutnya pada Siklus I diperoleh $53,75 \%$ dalam kriteria mulai berkembang dan pada Siklus II diperoleh 81,56\% dalam kriteria berkembang sangat baik.

Berdasarkan hasil penelitian dan kesimpulan di atas, maka peneliti mempunyai beberapa saran sebagai berikut: 1) Pembelajaran melalui media lotto warna hendaknya dilakukan dalam proses pembelajaran lebih lanjut dalam rangka peningkatan kemampuan kognitif anak dalam mengenal warna. 2) Kepada guru khususnya guru taman kanak-kanak diharapkan dapat mengimplementasikan pembelajaran menggunakan media lotto warna untuk meningkatkan kemampuan kognitif anak dalam mengenal warna.

\section{UCAPAN TERIMAKASIH}

Dalam penulisan skripsi ini, tentunya tidak terlepas dari bantuan dan dukungan dari berbagai pihak. Oleh karena itu, dalam kesempatan ini peneliti menyampaikan ucapan terima kasih kepada pihak TK. PLAMBOYAN MEKAR yang telah bersedia menerima penulis untuk melakukan penelitian. Keluarga tercinta dan Teman-teman PG PAUD yang telah begitu banyak memberikan do'a dan dorongan moril.

Aulad : Journal on Early Childhood, 2018, 1(1), $78-84$ 
DAFTAR PUSTAKA

Agung Triharso. 2013. Permainan Kreatif dan Edukatif untuk Anak Usia Dini Yogyakarta: Andi Yogyakarta

Arief S Sadiman, dkk. 2006. Media Pendidikan. Jakarta: PT Raja Grafindo Persada

Arikunto, Suharsimi dkk. 2006. Prosedur Penelitian Suatu Pendekatan Praktik. Jakarta: Rineka Cipta

Arikunto, Suharsimi dkk. 2010. Prosedur Penelitian Suatu Pendekatan Praktik. Jakarta: Rineka Cipta

Darma Prawira, Sulasmi. 1989. Warna Sebagai Salah Satu Unsur Seni Dan Desain. Jakarta: Departemen Pendidikan dan Kebudayaan.

Darma Sulasmi Prawira, 1989. Warna Sebagai Salah Satu Unsur Seni Dan Desain. Jakarta: Depdiknas

Depiknas. 2009. Peraturan Menteri Pendidikan Nasional Republik Indonesia

Eliyawati Cucu. 2005. Penelitian dan Pengembangan Sumber Belajar. Jakarta. Direktorat Pembinaan Pendidikan. Helmawati 2015. Mengenal dan Memahami PAUD. Bandung: PT Remaja Rosdakarya.

Jusni, Bainil. 2006. Proses Belajar Mengajar. Pekanbaru: Cendikia Insani

Mulyasa. E. 2003. Kurikulum Berbasis Kompetens; Konsep,Karakteristik dan Implementasi. (Bandung: PT Remaja Rosda Karya).

Musfiroh, Tadkiroatun. 2005. Bermain Sambil Belajar dan Mengasah Kecerdasan. Jakarta: Depdiknas

Nomor 58 Tahun 2009 tentang Standar Pendidikan Anak Usia Dini. Jakarta: Depdiknas

Nugraha Ali. 2008. Pengembangan Pembelajaran Sains pada Anak Usia Dini. Bandung: JILSI Foundation

Partini. 2010. Pengantar Pendidikan Anak Usia Dini. Yogyakarta: Grafindo Literia Media

Soewignjo, Santosa. 2013. Seni Mengatur Komposisi Warna Digital. Yogyakarta: TAKA Publisher.

Sudjana Nana. 2005. Media Pengajaran. Bandung: Sinar Baru Algensindo

Sujiono, Bambang Dan Yuliani Nuraini Sujinono. 2005. Menu Pembelajaran Anak Usia Dini. Jakarta: Yayasan Citra Pendidikan Indonesia.

Susanto Ahmad. 2015. Teori Belajar D an Pembelajaran Disekolah Dasar. Jakarta: Prenada Media

Susanto Ahmad. 2012. Perkembangan Anak Usia Dini. Kencana Prenada Media Group. Jakarta

Susanto Ahmad. 2013. Teori Belajar dan Pembelajaran di Sekolah Dasar. Jakarta: Kencana Prenada Media Group.

Swasty, Wirania. 2005. A-Z Interior Warna Rumah Tinggal. Penerbit Penebar. Swadaya.

Wahyuningsih Sri dan Muh. Munuf syamsudin.2011 . Model, media dan Evaluasi Pembelajaran Anak Usia Dini. Surakarta Modul PLPG 